\title{
HISTORICAL BACKGROUND \\ OF TAX SYSTEM FORMATION IN UKRAINE \\ IN THE TWENTIETH - EARLY TWENTIETH CENTURIES AND FEATURES OF NATIONAL FISCAL POLICY
}

\section{Krushelnytska T. A.}

\section{INTRODUCTION}

With the development of society and the state, theoretical disputes about the nature of taxes have raised around their nature and, more sharply, regarding their role in the state, and over time, with the new civilizational challenges, the scientific controversy does not cease. From a historical approach to the study of the tax system and the peculiarities of national fiscal policy, it becomes possible to determine the nature of the contradictions and inconsistencies that torment the integrity of the national tax system today, undermining the economy of the country. In addition, historical experience allows us to identify the cause and put an end to the unfolding of tax ambivalence between tax institutions and taxpayers.

In the early twentieth century in the academic environment of the Russian Empire (Ukraine was a part of which), there was an intense controversy over the theory of taxes, and it concerned mainly the problems of the nature of taxes, their forms, types, functions. The works of economists I. Ozerov, A. Sokolov, N. Turgenev, I. Yangul and others have become an valuable asset not only for national but also for global tax theory. After the October 1917 Revolution, due to political factors, the acquisitions of these and other eminent tax theorists have been forgotten, and the state's vision and fiscal targeting have changed in the country. In the Soviet period, tax theory underwent devastating destruction, which rejected the development of the country, public administration, and economy many years ago.

Therefore, one of the crucial components of the process of development of tax public administration in Ukraine is the formation of a modern tax system as the main source of financial support for the 
performance of state functions. Creating effective tax system of Ukraine is characterized by intensification of the contradictions between disparity modern forms of taxation issued from the practice of developed countries and a powerful legacy of command-administrative public administration. Even in modern Ukraine it makes visualizes now. These contradictions are amplified by mentality of citizens who do not want to pay taxes and historically predefined fiscal institutions, which tend to force the administrative methods of work.

\section{Forced-revolutionary taxation in the early twentieth century in the USSR}

In his works J. Stiglitz emphasized that the evolution of the role and functions of the state in public life was reflected in the functional purpose of the tax system, with which we fully agree ${ }^{1}$. The author argues that the fiscal orientation of the tax system and the compulsory nature of taxation persist regardless of the development of government functions ${ }^{2}$. The evidence of the creation and functioning of the tax system of Ukraine in the twentieth century, as in other post-Soviet states, denies the rigidity of not only the fiscal orientation of taxes, but also their existence.

From the beginning of its existence in 1917, while the absence of its own system, the financial system of the Soviet state was built on the institutions of tsarist Russia. The main income was the issue of money and contributions. The first Soviet taxes had no real fiscal significance, but were of the nature of class struggle and frank confiscation. For example, the RNK Decree of August 14, 1918 imposed a simultaneous levy on the maintenance of Red Army families, which was levied on owners of private trading companies who had hired workers. A decree of the Central Executive Committee and the RNK of October 30, 1918, introduced a one-off extraordinary ten-billionth revolutionary tax, which imposed the city bourgeoisie and the kulaks ${ }^{3}$.

\footnotetext{
1 Стігліц Джозеф Е. Економіка державного сектора. Пер. 3 англ. А. Олійник, Р. Скільський. Київ Основи, 1998. С. 232-235.

${ }^{2}$ Ibid , c. $232-234$.

3 Решения партии и правительства по хозяйственным вопросам. Сборник документов. 1917-1928 гг. : в 6-и т. Москва. Издательство политической литературы, 1957. T. 1. C. 212-214.
} 
As P.Hay-Nyzhnyk noted, in financial and taxational work of Ukrainian People's Republic (UPR) government of that period consists unreasonably belief, that for almost the entire period of the UPR power in the country was in a state of permanent search of money. State is funded by voluntary contributions, loans, disposable compulsory taxes and power requisitions that through tough force, harm the reputation of the Central Council, the State Treasury was filled mainly by excise duties, which were in the days of tsarist Russia, so it was quite easy to collect, but they did not generate enough revenue ${ }^{4}$. The haphazard fulfilling of the budget illustrated the 'one day' policy, without any reasonable plan and perspective ${ }^{5}$.

In a collapsed economy, money flow stopped and, as a result, its naturalization of economy and commodity relations took place, so the USSR government had to switch to natural taxation. The decree of the Central Executive Committee of October 30, 1918 'On the taxation of agriculture with a natural tax' on the principle of income tax introduced a natural tax levied on the introduction of part of agricultural products ${ }^{6}$. The tax was levied on surpluses (as it seemed to the government) of products beyond the needs of the farms under the progressive system, depending on the number of tens of crops, the number of farms and the number of family members. A special system of individual taxation has been established for the kulak farms. The local councils could have attracted the kulak farms to taxation under the higher standards. This gave broad authority to the representatives of local authorities and had a pronounced subjective character, to approach selectively the taxation of certain taxpayers and the size of the tax itself.

The priorities of the tax policy of the Soviet republic of that period were expressed by Lenin in 1919. In particular, it was envisaged that the RCP would pursue a progressive tax, income tax, and property tax in all cases where possible. In the era of dictatorship of the proletariat and state

\footnotetext{
${ }^{4}$ Гай-Нижник П. Податкова політика Центральної Ради, урядів УНР, Української Держави, УСРР (1917-1930 рр.). Київ. Цифра-друк, 2006. С. 143-147.

${ }^{5}$ Ibid, p. 143-147.

6 Решения партии и правительства по хозяйственным вопросам. Сборник документов. 1917-1928 гг. : в 6-и т. Москва. Издательство политической литературы, 1957. T. 1. C. $212-214$.
} 
ownership of the main means of production, he emphasized, the finances of the state should be based on the direct rotation of a certain part of the income from different state monopolies for the needs of the state ${ }^{7}$.

Due to the inability to sufficiently fulfill the state treasury, the next step was taken to tighten tax policy. Thus, RNA Decree of 11 January 1919 on a national scale was introduced Food allotment ${ }^{8}$, according to which the number of grain and grain fodder for public use distributed for the removal of the population between provinces. As a result of the introduction of the sub-distribution of peasants, not only the surplus food, but also some of the necessary products were removed. One of the features of the tax policy at that period are revolutionary taxes from the urban and rural population. As a basis for charging assigned class principle: in addition to solving financial problems (cash resources) performed as and politically well: fighting against wealthy citizens.

From the direct taxes of that period, it is necessary to name the industrial tax, which was levied on trade and industrial enterprises, as well as income tax. It also played a political function: as the capital grew, the tax rate progressively increased. In addition, the approach to taxation not only failed to produce the expected economic result, but on the contrary became a powerful disincentive in society, which led to the fact that according to Yu. Polyakov, the industry was in ruins, agricultural production in 1920 was only $50 \%$ of the pre-war level (1913), ,... almost all urban population was hit by strikes in the country ..." eliminate the threat of ,,... the death of the revolution", individual leaders were asked to abolish the firm price for bread, to allow the free trade of bread, which ,... would nullify” a civil war, and between peasants and power ,... peace would come" ${ }^{\prime 10}$. In the end, it forced “... the country's

7 Ленин В. И. Сочинения [изд. 4.]. Москва. Гос. издат. пол. литературы, тип. “Печатный двор". 1950. Т. 29. С. 118.

8 Про розкладку між губерніями зернових хлібів i фуражу, що підлягають відчуженню в розпорядження держави. Декрет PHК від 11 січня 1919 р. URL: http://www.pravoznavec.com.ua/books/letter/8/ kernel.php/624.

9 Поляков Ю.А. Переход к НЕПу и советское крестьянство. Москва. 1967. - С. 25. URL: yandex.ua/yandrearch?tex.

10 Павлюченков С.А. Орден меченосцев. Партия и власть после революции. 1917-1929. Монография. Москва. Собрание, 2008. Р. 50-51. 
leadership to change its attitude... to the economic course..."11, to change the tax policy, to review the taxation system of peasants, for all who at that time were almost the only taxpayers in the country.

The decision to lift agriculture and the economy as a whole, which was urgently adopted by the government and had to normalize economic relations and remove the economy from ruins, was the abolition of the food distribution and the introduction of a food tax. To this end, a resolution on the transition to a new economic policy (NEP) was adopted at the X Party Congress on March 21, 1921 , which was later developed in the Resolution of the Central Executive Committee on Replacing Food and Raw Materials ${ }^{12}$.

The resolution on the NEP opens a new stage in the development of public administration of the country's tax system. According to this document, the basic principles of the food tax were laid down and it was emphasized that the total amount of the tax should be reduced as the Soviet state's industry and transport were restored. Due to restrictions and, in some cases, virtually no cash circulation, the RNA Decree of April 21, 1921, "On the Natural Tax on Bread, Potatoes, and Oil Seeds", introduced natural taxes on these and, later, other types of agricultural production on the progressive principle of construction. About the peculiarity of taxation at that time was a form of payment of a natural tax. It was assumed that natural taxes could be paid in 18 different types of products, with the possibility of replacing each other in terms of a certain equivalent.

The government has made decisions about new taxable products, but the efficiency of administering natural taxes at the time is beyond criticism. Tax loses, as transportation and storage of products reached $40 \%$ of the amount of taxes collected. However, there was a catastrophic shortage of selected products to cover even the minimal state needs, so in order to eliminate the physical losses of products and their expensiveness, as it was charged by the Decree of the Central Executive Committee and the SNA of March 17, 1922 "On a single natural tax on

${ }^{11}$ Поляков Ю.А. Переход к НЕПу и советское крестьянство. М. 1967. - С. 25. URL: yandex.ua/yandrearch?tex.

${ }^{12}$ КПСС в резолюциях и решениях съездов, конференций и пленумов ЦК. Москва. Госполитиздат, 1983. Т.2. С.370-371. 
agricultural products for $1922 / 23^{, 13}$ entered only natural tax is established as the only weight unit - in pounds or wheat progressive recovery is determined by three factors: the amount of arable land eater (one person), provision of livestock and crops.

There is no consensus among scientists as to the value of the NEP in the construction of a socialist state. Indeed, “... the successes of the NEP were reflected in the relatively rapid recovery of industry, transport and agriculture, and in the creation of a viable financial system"14 [111, p. 82], the whole country was involved in the process of reconstruction, resulting in an unstable market link between the state and the peasant ${ }^{15}$. It is achieving this, albeit fragile-called 'communication gives us reason to believe during the NEP in one of the most advanced in the establishment and governance of the tax system in the Soviet state.

During the first 5 years, the restoration period, from 1921 to 1926, the index of industrial production increased more than 3 times, agricultural production increased 2 times and exceeded the level of 1913 by $18 \%$. But even after the recovery period, economic growth continued at a rapid pace: in 1927 and 1928, industrial production growth was 13 and $19 \%$, respectively. On the whole, during the period $1921-1928$, the average annual growth rate of national income was $18 \%{ }^{16}$. However, in spite of the general optimistic picture reflected in the historical sources of those times, A. Drozdukov emphasizes, the contradictions between the state and the population, between agriculture and industry became more and more aggravated “... as the problems of modernization of the country were brought to the fore" ${ }^{\prime 17}$. N. Rogalina generally insists on the doom of the NEP because of the limited market of that period, “... which made economic decisions politically possible" ${ }^{\prime 18}$. Let us mention, indeed,

\footnotetext{
${ }^{13}$ Єдиний сільськогосподарський податок на 1923-24 pp. Декрет та постанова. Харків. : Видав. відділ Наркомпроду, 1923. 16 с.

14 Дроздюков А. В. Итоги НЭП сквозь современную историографию. Инновационное образование и экономика. Москва. .2007. № 12 (1). С. 82.

15 Дэвис Р. Развитие советского общества в 20-е годы и проблема альтернативы. Россия в ХХ веке: историки мира спорят. Москва. 1994. Р. 214.

${ }_{16}$ Дроздюков А. В. Итоги НЭП сквозь современную историографию. Инновационное образование и экономика. 2007. № 12 (1). С. 82-87.

${ }^{17}$ Ibid, p. 85.

${ }^{18}$ Рогалина Н. Л. Новая экономическая політика и крестьянство Нэп: приобретения и потери. Сборник статей. Рос. АН. ин-т рос. истории; отв. Ред. В. П. Дмитренко. Москва : Наука, 1994. С. 142-143.
} 
the NEP as the economic policy of the Soviet state was gradually supplanted and eradicated. However, its undisputed achievement was the promotion of the material base for the establishment of statehood in the USSR, including through the taxation of private activity, which became possible only due to the temporary softening of state policy towards independent private business activity.

An important result of the NEP was that economic successes were achieved on the basis of fundamentally new, unknown before the history of public relations of the state and the private owner. Thus, at that time in the industry key positions were occupied almost exclusively by state trusts, in the credit and financial sphere - state and cooperative banks, and in agriculture - small peasant farms, private or covered by simple types of cooperation. According to this completely new under the NEP were economic functions of the state have changed radically and priority objectives, budget and fiscal policy. Previously, the Center had directly forced the natural and technological proportions of reproduction into order, but now it has moved to regulating prices, seeking indirect, economical methods to ensure balanced growth.

The industrial sector of the economy, which is now largely stateowned, has not been left out of taxation by the USSR government. In 1926, income tax on state-owned enterprises, cooperative organizations and joint stock companies with participation of state and cooperative capital in the amount of $8 \%$ of the amount of net income ${ }^{19}$.

But the most interesting, in our opinion, the achievement of the NEP was the temporary weakening of the tax press on most peasant farms (except for the kulak ones). During the NEP embryos preferential taxation appeared, for example, granted tax relief cooperative organizations $^{20}$, the sole Agriculture (low income, low marginal farms, and those that grow industrial crops) were first established exemption limit (Article 212) ${ }^{21}$. Some cooperatives (consumer, agricultural, handicraft, handicraft and credit) were exempted from industrial

\footnotetext{
${ }^{19}$ Davis R. From Tsarism to tse New Economic Policy. London. 1990. C. 62.

20 О льготах по обложению промысловым налогом для некоторых категорий предприятий : Постановление Наркомфина CCCP от 25.09.1923 URL: http://www.bestpravo.ru/sssr/eh-gosudarstvo/j7b.htm

21 О едином сельскохозяйственном налоге на 1928-29 год : Положение : Постановление ЦИК и СНК СССР от 21 апреля 1928 г. Собр. законодательства СССР. 1928. № 24. С. 212.
} 
$\operatorname{tax}^{22}$. With regard to individual income, during this period, the income $\operatorname{tax}^{23}$ was in force, which in 1926 was replaced by the state income tax, it provided for the application of the tax-free minimum and the taxation of income of citizens in the calculation of all members of their families who do not have independent income ${ }^{24}$. To confirm the fact of introducing softer tax policy, present observations, R. Davis and, according to which the share of land tax and payments for land in income of farms declined from $9.5 \%$ in 1913 to $4.9 \%$ in the year $1926 / 1927^{25}$. But in the future tax burden has been strengthened, but even a temporary easing tax burden is a good example of successful historical problems the state budget using promotional tools.

Also there is no doubt that the main task of the state remained the transition to full progressive income taxation of individuals and businesses and strengthen of the tax burden on kulak farms. Lenin proclaimed to the delegates of the 10th All-Russian Party Conference that tax collection would not go voluntarily, he would not do without coercion $^{26}$. That is, as in previous years, the state used violent methods of tax collection, and indirect taxes were introduced in the form of various excise taxes, as the implementation of the further expansion of the list of taxable objects by the government.

For the peasants, Yu. Polyakov notes, that NEP “... meant taxes known in advance" 27 , which helped to strengthen the economy of the economy, but caused concern for the leadership of the party and the government, which in this phenomenon was seen by the factors of growth of the „kulak" layer ${ }^{28}$. Subsequently, fears about the

22 О льготах по обложению промысловым налогом для некоторых категорий предприятий : Постановление Наркомфина CCCP от 25.09.1923 URL: http://www.bestpravo.ru/sssr/eh-gosudarstvo/j7b.htm

23 Об изменении ст. ст. 7 и 9 Положения о государственном подоходнопоимущественном налоге : Постановление ЦИК ССCР, CHК CCCP от 27.07.1923 p. URL: http://www.bestpravo.ru/sssr/eh-gosudarstvo/y2o.htm.

${ }^{24}$ О введении в действие Положения о государственном подоходном налоге : Постановление ЦИК СССР, СНК СССР от 24.09.1926 URL: http://www.bestpravo.ru/ sssr/eh-dokumenty/n0r.htm.

${ }^{25}$ Davis R. From Tsarism to tse New Economic Policy. London. 1990. С. 62.

${ }_{26}$ Ленин В. И. Сочинения [изд. 4.]. Москва: Гос. издат. пол. литературы, тип. «Печатный двор». 1950. Т. 29. Р. 118.

${ }^{27}$ Поляков Ю.А. Переход к НЕПу и советское крестьянство. Москва. 1967. С. 35. URL: yandex.ua/yandrearch?tex.

${ }^{28}$ Ibid, p. 35. 
strengthening of the pulpit were increasingly reflected in the formation of a forfeiture tax policy.

As a result of the changes made in the late 20-ies of the twentieth century in the USSR formed a complex and cumbersome tax system: at that time there were 86 types of payments to the budget. Due to this , V. Lytvyn notes that since 1923/24 of the economic year in Ukraine “... eating of fixed capital" in industry has stopped ${ }^{29}$. In the following, the extended reproduction process began in 1924/25, and in $1925 / 26$.,... some of the capital investment was directed to new buildings" ${ }^{\prime \prime}$, but, as before, the funds for implementing the ambitious plans of the ruling party were not enough.

The Soviet government issued loans to finance the state industrialization program (which had fiscal signs because it was compulsory and compulsory). The first loan reached 200 million rubles, was issued in 1927, the budget received 198 million rubles, including the USSR - 34 million rubles. The second loan, in 1928, gave the budget 517 million rubles, incl. Ukraine - 96 million rubles ${ }^{31}$. Government loan receipts exceeded expectations, but the volume of sources did not cover the needs of industry, ,... which absorbed far more than planned" ${ }^{\prime 32}$. In the five years, the industry was to give 12 billion rubles., V. Lytvyn, emphasizes the profit and gave only 6.949 billion. Thus, the sums needed for " ... the forced development of the industry could only be received from the peasants", that is, the need remained "... to strengthen the press on the collectivized village ...”, writes N. Hryk ${ }^{33}$. After all, writes V. Golovko, agriculture has become the only source of income for capital investment in the modernization of industry and the army of the

29 Литвин В. М. Криза непу. Історія України: підручник. 2011. URL: http://www. Lytvin-v.jrg.ua/history_of_ukraine/mdex.php?article=ch.

${ }^{30}$ Ibid.

${ }^{31}$ Ibid.

${ }^{32}$ Грик Н. А. Сельское хозяйство и промышленность: взаимодействие и взаимосвязь в годы первой пятилетки. 2006. P. 3. URL: lib.tusur.ru/fuletext/periodika/oglavl/ 2006_grik_220906pdf.

${ }^{33}$ Грик Н. А. Сельское хозяйство и промышленность: взаимодействие и взаимосвязь в годы первой пятилетки. 2006. Р. 1. URL: lib.tusur.ru/fuletext/periodika/ oglavl/2006_grik_220906pdf 
$\mathrm{USSR}^{34}$. However, scholars of that time were rather optimistic about the taxation of peasants. Thus, M. Mitilino believed that “... agriculture has reached such a level that it is possible to increase the burden of taxation" "35, and this "... will help the restructuring of the village..."

The experience of those years proved the fallacy of this assumption. Due to the definition of industrialization as a priority objective of the budgetary and economic policies of the Communist Party leadership, the nature of taxation has changed significantly. The country has finally established a rigorous tax burden of expropriation on the traditional agrarian sector, which provoked a fall in the income level of peasants, caused migration of the rural population to the cities. Tax policy and other confiscation factors were pushing peasants into the city, which prepared the basis for an initial industrial leap in the USSR.

Since 1929, radical changes have taken place in the development of agriculture. Government was proclaimed on policy of collectivization, he was accompanied by further increasing the tax burden and the transition to the forced collection of taxes. Therefore, in the period 1929-1933, we distinguish in a separate stage of development of the tax system, as the tax policy of the country has acquired new aspects: it has become aimed at solving the problems of collectivization of the village, support and strengthening of the collective farm system, the final elimination of kulaks.

Why was the fiscal pressure exerted on the kulaks and why did communist propaganda call them class enemies? Turmeric was called a fairly large proportion of landowners in Ukraine (not that small or large), who mostly used hired labor to cultivate the land. The Soviet government, the leadership of the Bolshevik Party (later the Communist Party) saw the threat of political resistance from these masters, as opposed to the proletarians, who lost nothing and were already dependent on the state machine, landowners remained independent not only economically but also free of their own. Decisions, actions, were able to resist the repressive state

\footnotetext{
${ }^{34}$ Головко В. "Модернізація” як метанарратив української історії. Проблеми, історії України: факти, судження, пошуки : історичн. журнал. - 2003. № 9. С. 424.

${ }_{35}$ Мітіліно М. І. Основи фінансової науки. Київ. Державне видавництво України, 1929. P. 164

${ }^{36}$ Ibid. P. 166.
} 
machine of the time, which, in fact, they did. Therefore, tax policy and the period of the NEP, and later, as a lever for pressing and, ultimately, the elimination of the capitalist elements - 'kurkuls'. But in fact, a large layer of citizens, capable of managing the economy, thinking critically, making economic and managerial decisions, was liquidated. Such a repressive and confiscatory nature of tax policy has resulted in the great tragedy of the Ukrainian people, which is still evident today.

The main government documents in the field of tax changes were the Resolution of the Central Executive Committee and the RNA of February 8, 1929 "On the Single Agricultural Tax and the Facilitation of Taxation of the Medium-Sized Economy" and in the Regulation "On the Single Agricultural Tax for 1929-30"37. The object of taxation under this provision was the total income of the economy. Further encouraging collectivization in the „About the only agricultural tax in 1930-31 years”. Approved by the CEC and SNK on February 23, 1930, for the collective instead of progressive and at taxation was set proportional. Under the new regulation, three taxation systems were approved: collective farms, single-occupied labor and kulak farms. At the same time, the criteria of attribution of farms to the kulak ones were expanded, and the taxation was carried out individually, which had a frank subjective, or more precisely, forced-confiscation character.

Changes and reforms in tax policy have affected not only the agricultural sector. In 1930-1932, a radical tax reform was carried out in the USSR, which resulted in the abolition of the excise tax system, instead of all tax payments (about 60) of enterprises that were at that time were exclusively state-owned, unified into two major ones: turnover tax and income tax deduction.

By the end of the 30-ies of the twentieth century, in the USSR there was decline in consumption in urban and rural areas, has acquired distribution extracting resources in the rural population, which was of hard to force, confiscation nature of tax policy and determines the orientation of fiscal policy to address the problems, ignoring the well-being and, even life. Thus, one of the most significant repressive measures against the peasants

${ }^{37}$ Єдиний сільськогосподарський податок 1929-30 pр. : Декрет НКФ УСРР. - Харків. Укр. філія Держфінвидаву СРСР, 1929. - 48 с. 
of Ukraine in their numerous streams was the one-time tax introduced for single peasant households of Ukraine, approved on November 19, 1932 by the Resolution of the CEC and RNA. According to this document, the RNA of the USSR and regional executive committees were instructed to "set tax rates for districts, based on the economic characteristics and conditions of each district..." and "... to ensure constant systematic control over class tax administration..."38. The tax was introduced to eliminate income of individual households that were not taxed agricultural tax, the result of his (among others) became Holodomor 1933. The complexity and depth of state priorities in fiscal policy are partly covered by data on the dynamics of socio-economic indicators in the USSR in the late 1920s and early 1930s (Table 1.4) (calculated according to according to ${ }^{39}$ ).

Data shows, on the one hand, rapid, more than in $200 \%$, economic growth, which reflects the realization of the intentions of the Communist Party leadership and the USSR government to industrialize the country, and on the other, the inordinate price of this growth, which is measured by the millions of lives lost in Ukraine: in 1933 In 2006, 166 people were paid for each tractor that came to the Ukrainian village.

Since the early 1930s, as before, and for quite a long time to come in the USSR, taxes have been exercised by their functions that are not peculiar to them: political and class struggle. In the course of collectivization and industrialization, practically complete destruction of the kulaks in Ukraine, destruction of market approaches to production and sale of products, general extension of state ownership to almost complete monopoly took place, which allowed to build a system of taxation on administrative methods by withdrawing the profits of enterprises and redistribution of financial resources through the country's budget.

38 Про одноразовий податок на одноосібні господарства : Постанова Раднаркому УСРР від 21 листопада 1932p. URL: http://textbooks.net.ua/content/view/1073/17/.

39 Смирнов В. С. Экономические причины кризиса социализма в СССР. Отечественная история: РАН. Ин-т рос. истории. 2002. № 6. С. 97. 
Table 1.4

Social and economic indicators of the USSR

in the late 1920s -early 1930's

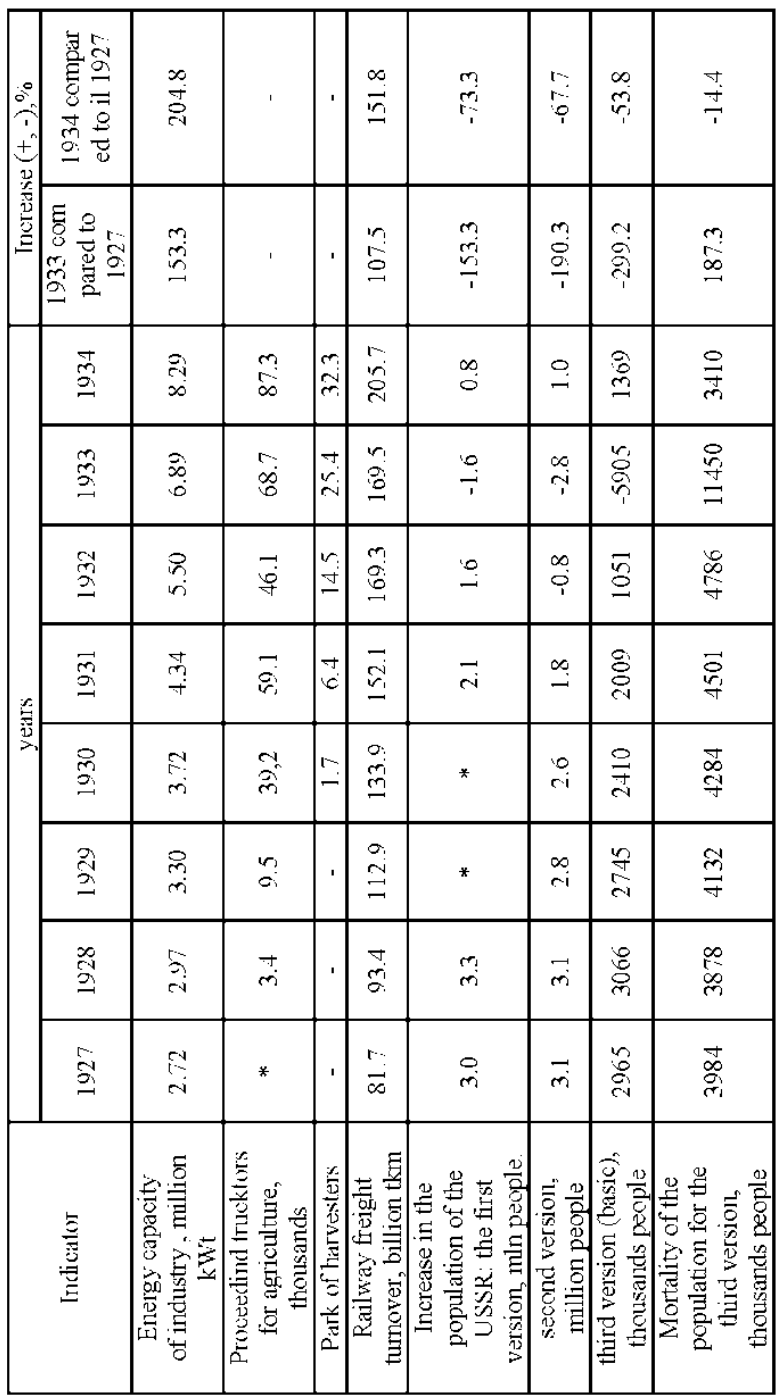


The formation of new priorities of the tax policy of the state has emerged since 1936, which allowed us to highlight the beginning of the next period of tax development in the USSR. It is characterized by complete management of resources by the state, determination of planned tasks and "control figures", establishment of "state orders", directions, volumes and prices of sold products, etc. ${ }^{40}$. With the help of "... central planning, the state monopolized the market", managed the objects, "... appropriation of the product created at state enterprises and monopoly profit..." 41 . The renewed income of the state was formed not by taxes, but by direct deductions of the gross national product, on the basis of “... absolute state monopoly" ${ }^{42}$. This feature, in our view, remains a difficult historical legacy in the field of public administration of the tax system.

The result of this approach was the almost complete loss of fiscal function taxes, given that population taxes were not significant, the existence of the tax system lost sense, and the state fiscal policy was transformed into a purely budgetary one: centralized withdrawal, centralized distribution. In the structure of public administration, which was regulated by the Constitution of the $\mathrm{USSR}^{43}$, approved by the Extraordinary VIII Congress of Soviets of the USSR on December 5, 1936, tax service as an institution of public administration was designed to collect taxes, until $1990^{44}$.

\section{Prerequisites for forming a tax system in an independent Ukraine. Restoration of tax system institutions}

During the period from 1936 to 1987, tax events took place, but they were not of a profound reformer character. In those years, in Ukraine, as well as in the Soviet Union as a whole, in science, awareness of the

\footnotetext{
${ }^{40}$ Бодров В. Г., Крушельницька Т. П., Манойленко О. В., Мартиненко В. Ф. Державне регулювання спеціальних монополій в Україні : наукова монографія. Х. : Вид-во "Константа", 2005. p. 25-26.

${ }^{41}$ Ibid. P. 25-26.

${ }^{42}$ Ibid. P. 25.

${ }^{43}$ Конституция (основной закон) СССР от 5 декабря 1936 года (с последующими изменениями и дополнениями) URL: http://www.hist.msu.ru/ER/Etext/cnst1936.htm.

$44 \mathrm{O}$ государственной налоговой службе : Постановление Совмина СССР от 24.01.1990 N 76. URL: http://www.bestpravo.ru/sssr/gn-akty/q0p.htm.
} 
essence of taxes was reduced to its ideological and class content, and tax in 'bourgeois' states was defined as a tool of exploitation. From 30 years up to the collapse of the former Soviet Union and in the entire country, no problems Ukraine's development tax system no one cared, because I for said Victor Panskov, in that ,... there was no need: society legislated to build the world's first tax-free state". This has led national science in this field for a long time to clear the theoretical understanding of the nature and nature of taxes, to determine their role in public administration, which explains the irrational trajectory of tax reform, which echoes even today.

During this period, the tax pressure intensified (to financially support the urgent needs of the state), then weakened (to illustrate the „extraordinary acts of the ruling party”). Example, the collective farm taxation has changed since 1936 after the adoption of the CEC and RNA Decree of June 20, 1936 "On the replacement of agricultural monetary tax by collective farms with a profitable monetary tax" ${ }^{~} 45$. It was a softening of fiscal policy, which explained uneven taxation of certain types of agricultural enterprises. Profit tax has significantly simplified and reduced the cost of collection and facilitated the organization and strengthening of collective farms.

With the World War II, there has been an increase in taxation due to the need to meet military needs. A military tax (abolished in 1946) was introduced in 1941 and a $100 \%$ agricultural tax surcharge was subsequently abolished. In order to raise additional funds for mothers of many mothers, the Order of the Presidium of the Supreme Soviet of the USSR introduced, on November 21, 1941, a tax on bachelor, single, and small family citizens ${ }^{46}$, which was expected to promote population growth and provide additional collection for large families.

In the post-war period, a tax was introduced on the turnover of trade enterprises, an analogue of excise duty on consumer goods (crystal, furniture, coffee, cars, vodka). Income from this tax in the revenue part

${ }^{45}$ КПСС в резолюциях и решениях съездов, конференций и пленумов ЦК. Москва. Госполитиздат. 1983. Т. 2. С. 370-371.

${ }^{46}$ Про податок на холостяків, одиноких і бездітних громадян СРСР : Указ Президії Верховної Ради СРСР від 21 листопада 1941 року. Відомості Верховної Ради СРСР. 1941. N 42. 
of the budget in 1954 was $41 \%{ }^{47}$, the collection of livestock owners ${ }^{48}$, etc. The gradual replacement of taxation by non-tax sources of budget replenishment has also returned. Chief among them was the redistribution of part of the revenues of state-owned enterprises and organizations with the simultaneous payment of turnover tax, which in 1954 accounted for approximately $40 \%$ of the revenue part of the budget of the $\mathrm{USSR}^{49}$.

It should be noted that a certain impetus in the change in tax policy occurred with the advent of the top management of the country Khrushchev. The reasons for the revival of tax activity in the late 1950s were due to a shortage of payments on domestic government liabilities, a manifestation of the government's refusal to extinguish government bonds in 1957 due to severe economic problems ${ }^{50}$. As a result, the unemployment rate in the country increased, though not officially registered, the deficit of goods increased, and other signs of crisis were observed, which required urgent measures on the part of the state.

It was against the background of the worsening economic crisis that Khrushchev put forward the idea of sacrificing small, as he thought, budget revenues from taxes on the income of the population, in order to maintain the party's priority position. Leaders from proposed restructure management of the economy, yet ,press red directors”, and production will rise and float in budget revenues ${ }^{51}$. Indeed, according to the data given by E. Zhirnov, taxes on the population in the mid-60's of the twentieth century. In the USSR, they accounted for less than $8 \%$ of state revenues, and, as the first secretary of the CPSU Central Committee,

47 Цыпкин С. Правовое регулирование налоговых отношений в СССР. Москва. Госюриздат, 1955. Р. 17.

${ }_{48}$ Соколовська А. М. Методологічні аспекти оподаткування. Наукові праці НДФІ. 2001. Вип. 2 (14). p. 33.

49 Брызгалин А. В. Налоги и налоговое право. Учебное пособие под ред. А. Брызгалина. Москва. 1997. 600 c. URL: http://www.cnfp.ru/tax/theory/history/.

50 Подписка о невыплате. Власть. 2007. № 10. URL: http://www.kommersant.ru/ vlast/?IssueID $=55315$.

51 Жирнов Е. Отказаться от взимания налогов. Комерсант. Власть. 2010. № 17-18. URL: www.kommersant.ru/ doc.aspx?DocsID=1361006). 
M. Khrushchev, believed, the loss of such an amount could not have made the budget a ,non-renewable gap",52.

Proclaiming the program "... active construction of communism", for the 21st Congress of the CPSU in 1959, the USSR government made proposals for the abolition of taxes on the population, which envisaged the gradual abolition of the payroll tax for workers and employees, starting in May $1960^{53}$ [308]. In this regard, the third Program of the CPSU, adopted at the XXII Congress of the CPSU on October 31, 1961, provided for the complete abolition of tax payments from the population $^{54}$. The reforms proposed in the 1960s, inspired by the "coming of communism, "included the complete abolition of taxes and the introduction of a system of income payments, payment for the fund and normalized working capital instead. Government documents stated : as a result of the reform, "... a high level of material and technical base will be created, a high level of consciousness of the people will be achieved, the principles of socialism will be fully developed and fully demonstrated" 55 .

The main contradiction of the reform of 1965 is the desire of the authorities to maintain a policy model of the departmental economic mechanism and, at the same time, to combine two opposite processes: to strengthen centralization in the economy and to engage market economic regulators (profitability, profit, etc.). Market ideas do not fit into the economic mechanism USSR, the essence of which was saved of all power in the hands of the state. Accordingly, the tax system was set up by the state to function in an unaltered, directive way.

The reform of the economy, including the tax system, in terms of complete abolition of taxation of citizens, in this form was not adopted. Subsequently, significant changes were made to the tax legislation acts regarding burdening of income tax, property taxation of individuals, agricultural tax, single state duty, collection for housing and cultural and household needs, income tax from film screenings, etc.

\footnotetext{
${ }^{52}$ Ibid.

${ }^{53}$ Об отмене налогов с заработной платы рабочих и служащих : Закон СССР от 7 мая 1960 года. Ведомости Верховного Совета СССР. 1960 . № 18. Ст.135.

${ }_{54}^{54}$ Программа КПСС. Принята ХХІІ съездом КПСС. Москва, 1974. С.28

${ }^{55}$ Ibid. P. 28.
} 
Although the implementation of this resolution has not occurred due to shift Khrushchev from office, in the States and in the tax system and has already begun significant changes. Due to them in 1970 there was originated elementary tax system administrative-command direction of individual tax items, such as personal income tax. At the beginning of the reforms of the mid-1980s, more than $90 \%$ of the State budget of the Soviet Union and its individual republics was formed at the expense of the national economy. Direct taxes on the population accounted for a small proportion, approximately $7-8 \%$ of all budget revenues $^{56}$.

In the 1971-1985 the command-administrative system could not adapt to the demands and changes dictated by the scientific and technological revolution, which, along with other factors, have become a major cause of extinction disproportional economic development. The necessary resources were gradually exhausted or significantly more expensive, and the economic growth of the USSR declined rapidly. Thus, the average annual growth rate of industrial production was: in 1966-1970 about $8.5 \%$; in 1971-1975 - 7,4\%; in 1976-1980 - reached only $4.4 \%$; and in 1981-1985 - fell to $3.6 \%$, and the growth rate of national income in the same periods amounted to 7.2, 5.1, 3.8 and $2.8 \%$, respectively ${ }^{57}$. There was a gradual impoverishment of the country; the Soviet economy entered the stagnation zone. The signs were an increase in the budget deficit, a constant monetary issue, and an increase in the national debt.

Against this background, there was an increasing need for a restructuring and gradual transition to new economic conditions, which envisaged the resumption of individual employment at non-state enterprises, and therefore the need for a state institute to manage a new process, such as the tax one, was at the moment a question about the revival of the tax service and the development of the tax system as a whole.

The impetus for the creation of the tax service of the USSR was the measures that were gradually to bring the economy from command to

\footnotetext{
56 Леоненко П. М., Юхименко П. І. Економічна історія. Навчальний посібник. Київ. Знання-Прес. 2004. С. 70.

${ }^{57}$ О государственном предприятии (объединении). Закон CCCP от 30.06.1987. URL: http://pravo.levonevsky.org/ baza/soviet/sssr1996.htm.
} 
administrative to market. For example, in 1986 the USSR allowed individual labor activity of citizens, in accordance with the provisions of the Law of the USSR of June 30, 1987 „On State Enterprise (Association)", set a patent for the right to engage in individual employment [300]. Adoption of this law can be considered the beginning of a radical reform of the system of mandatory payments to the budget in the USSR, it was the beginning of the formation of a legal framework for the introduction of a system of taxes for individual entrepreneurs, cooperatives and enterprises with the participation of foreign organizations, the impetus to the emergence of state and fiscal policy on a qualitatively new level of development. Important steps towards the formation of a new tax outlook were the Laws on Individual Labor Activity (1986), and On Cooperation (1988), which legalized small-scale private entrepreneurship and prepared the ground for taxation.

As a result of the state decisions taken, in 1988, 734 thousand people were employed in individual labor activities, mostly handicrafts. The rapid dynamics of the number of cooperatives in these years testifies to the timeliness and foresight of the decisions made. Thus, in the spring of 1989, the number of cooperatives exceeded 99.3 thousand people, employing about 2 million people, and two years later, in 1991, this figure exceeded 7 million people, representing about $15 \%$ of the country's active population ${ }^{58}$.

Thus there were launched reforms whose aim was to claim transition from administrative to economic methods of governance. Due to the increasing flow of information of various kinds, caused by the lifted "Iron Curtain", it became increasingly impossible to ignore the global trends in the development of the tax system, thus preparing the ground for the creation and formation of the tax system of Ukraine as an institution of state power for the implementation of fiscal policy. With the adoption in 1987 of the USSR Law on State Enterprise (Association) $^{59}$, which became effective for all enterprises, a separate

\footnotetext{
58 Леоненко П. М., Юхименко П. І. Економічна історія. Навчальний посібник. К. : Знання-Прес. 2004. 499 с.

${ }^{59}$ О государственном предприятии (объединении). Закон CCCP от 30.06.1987. URL: http://pravo.levonevsky.org/ baza/soviet/sssr1996.htm.
} 
period was opened, the Soviet development of the tax system, which was characterized by a radical reorientation of tax policy towards legalization and promotion of development of individual entrepreneurship and the beginning of the formation of market relations.

As Ukraine obtained independence, a national tax system began to be created and intensively developed in our country. The State Tax Service of Ukraine was created by the decision of the Council of Ministers of the USSR of 12.04.90, No. 70. In December of that year, the Supreme Soviet of the USSR adopted the Law "On State Tax Service in the Ukrainian SSR" ${ }^{60}$. The status of the State Tax Service in Ukraine, its functions and legal bases of activity were regulated by the Law of Ukraine "On the State Tax Service in Ukraine" and the Decree of the Cabinet of Ministers of Ukraine "On Provision of Activities of the State Tax Administration of Ukraine".

In 1991, the Law of Ukraine "On the Taxation System" was adopted, which defines the principles of building a taxation system in Ukraine, a list of taxes and fees (mandatory payments) to budgets and state trust funds, as well as the rights, duties and responsibilities of payers. The system of bodies of the state tax service of Ukraine according to the above law included: State tax administration of Ukraine and state tax inspections. The period of formation of the tax system of independent Ukraine begins. The main focus was on regulating economic issues affecting the quantitative focus of taxes, the size of tax rates and the distribution of tax payments across budgets at different levels ${ }^{61}$. Adoption of this law was the beginning of formation of tax system institutions in independent Ukraine. The creation of tax system institutions was caused by the reform of economic and political relations

From 1991 to 1996, the tax system of Ukraine takes on a certain legal form, with limited compliance with the global trends of formation and functioning. From such positions, at this stage, we define the state's goal of the role of the tax system as to bring the normative provisions of the

${ }^{60}$ Про державну податкову службу в Україні. Закон України від 04.12.1990 № 509XII. Офіційний веб-сайт Верховної Ради Украӥни. URL: http://zakon3.rada.gov.ua/laws/ show/509-12.

${ }^{61}$ Про систему оподаткування. Закон України від 25.06.1991 № 1251-XII. Офіиійний веб-сайт Верховної Ради України. URL: https://zakon.rada.gov.ua/laws/show/1251-12 
tax system of Ukraine to the requirements of world standards and, taking into account the growing share of the private sector of the economy, fulfill the fiscal function. An example of an attempt to rise to world standards was, for the first time in the tax practice of Ukraine, the mandatory declaration of personal income ${ }^{62}$. But the most obvious in the sense of forming a tax system on world models was the introduction of value added tax (previously - added value), since, according to A. Sokolovska, in most developed countries, the formation of financial needs of the state is mainly due to indirect taxes ${ }^{63}$.

With the adoption of new laws on income tax and value added tax in 1996 and 1997 respectively $^{64,65}$, for the first time in the current legislation introduced the concept of tax accounting, identifies the objects of taxation, without reliance on accounting, introduced the concept gross expenditures and gross revenues, the algorithm of budgetary compensation of VAT is formed, etc.

An important step taken during the new stage of tax system reform was made on May 22, 2003, with the adoption of the Law of Ukraine „On Personal Income Tax", which came into force on January 1, 2004. The main innovation of this law is the detailing of terms, a significant reduction in the tax rate, simplifying its definition, and so on. Thus, since January 1, 2004, it has been set at 13\%, regardless of the size and place of income, and since January 1, 2007 the rate is $15 \%$, unlike the earlier CMU Decree ${ }^{66}$. It should be noted that until 2004 there was a progressive, abrupt taxation rate for individuals, which was difficult to justify. The changes, innovations and additions made at this

${ }^{62}$ Про прибутковий податок з громадян : Декрет КМУ від 26.12.1992 № 13-92. Офіційний веб-сайт Верховної Ради Украйни. URL: http://zakon.rada.gov.ua/cgibin/laws/main.cgi?nreg=13-92.

${ }_{63}$ Соколовська А. М. Податкова система України: теорія та практика становлення. Монографія. К. : НДФІ, 2001. Р. 34.

64 Про оподаткування прибутку підприємств. Закон України від 22.05.1997p. № 283/97-ВР. Офіиійний веб-сайт Верховної Ради Украӥни. URL: http://zakon.rada.gov.ua/ cgi-bin/laws/main.cgi?nreg=283\%2F97-\%E2\%F0.

${ }^{65}$ Про податок 3 доходів фізичних осіб. Закон України від 22.05.2003. № 889-15. Офіційний веб-сайт Верховної Ради Украӥни. URL http://zakon2.rada.gov.ua/laws/show/ 889-15.

${ }^{66}$ Про податок $з$ доходів фізичних осіб. Закон України від 22.05.2003. № 889-15. Офіційний веб-сайт Верховної Ради Украӥни. URL http://zakon2.rada.gov.ua/laws/show/ 889-15. 
stage to the tax regulations aimed at further bringing the domestic tax system to the world standards, on the one hand, and on the other, expanding the tax base to increase budget revenues.

Despite the fact, that quite a large number of regulations in Ukraine is still a problem perfect legal regulation of taxation. The relationship between the taxpayer and the state is not regulated as fully as we would like, legislative rules and are not uniquely is subjected to constant interpretation and, quite controversial changes.

In 2010 the Tax Code was adopted. The Code refers not just about reducing the list of taxes and reducing their rates, even though these measures will have a positive result in the stimulation of the economy, and the establishment of new mechanisms for tax collection, broadening the tax base, involvement of an increasing number of taxpayers, as well as changing the very ideology of taxation. It was expected that its adoption may provide a gradual transition to stabilization the fiscal law, automatic unopposed (in terms of variability of decision-making in the field) fiscal policy.

However, analyzing its provisions and implementation practices during 2011-2015, we see that the Code pays insufficient attention to the problems of eliminating legal loopholes, resolving tax collisions, improving the legal regulation of the entire tax relations system. This does not allow us to define the development of democracy and a market economy as priorities of fiscal policy in Ukraine. But tax system since Ukraine's independence, even given some positive provisions of the Tax Code, virtually unchanged base visualizes through two main functions of taxes, and fiscal control. That is why the tax system again needs a radical reform, which, in fact, has been started since 2015, taking into account the needs of governmental and budgetary decentralization.

The main results on the analysis of scientific sources and normative documents adopted during the twentieth century XXI in the USSR and independent Ukraine, the author highlights the main stages of the origin 
and formation of the national tax system, which are caus by the evolution of policy on the role of tax (Table. 2) ${ }^{67,68}$

Table 2

Stages of formation of the tax system of Ukraine

\begin{tabular}{|c|c|c|c|}
\hline Period & $\begin{array}{l}\text { Defining } \\
\text { regulations }\end{array}$ & Signs of the period & $\begin{array}{l}\text { Problems of } \\
\text { fiscal policy }\end{array}$ \\
\hline 1 & 2 & 3 & 4 \\
\hline $\begin{array}{l}\text { 1917-1921- } \\
\text { forced- } \\
\text { revolutionary }\end{array}$ & $\begin{array}{l}\text { RNA Decree of } \\
\text { October } 24,1917 \\
\text { "On the Collection } \\
\text { of Direct } \\
\text { Taxes"; RNA } \\
\text { Decree of January } \\
\text { 11, } 1919 \text { "On the } \\
\text { Food Layout" }\end{array}$ & $\begin{array}{l}\text { Confiscation and class } \\
\text { character of taxation; } \\
\text { the presence of } \\
\text { a disincentive natural } \\
\text { tax. }\end{array}$ & $\begin{array}{l}\text { Ensuring the financial } \\
\text { and food needs of the } \\
\text { state, most of all the } \\
\text { army. }\end{array}$ \\
\hline $\begin{array}{l}1921-1929- \\
\text { forcible } \\
\text { confiscation }\end{array}$ & $\begin{array}{l}\text { Resolution of the } \\
\text { Central Executive } \\
\text { Committee of March } \\
21,1921 \text { "On the } \\
\text { replacement of food } \\
\text { and raw materials } \\
\text { layout", RNA } \\
\text { Decree of April 21, } \\
1921 \text { "On the natural } \\
\text { tax on bread, } \\
\text { potatoes and oil } \\
\text { seeds" }\end{array}$ & $\begin{array}{l}\text { Natural and form } \\
\text { collecting taxes along; } \\
\text { refusal to pay taxes on } \\
\text { different types } \\
\text { of products, } \\
\text { establishing a single } \\
\text { product type, } \\
\text { softening the } \\
\text { taxation policy for } \\
\text { peasants; introduction } \\
\text { of separate tax } \\
\text { benefits; the } \\
\text { transition to } \\
\text { a progressive- tax } \\
\text { method. }\end{array}$ & $\begin{array}{l}\text { Restoration and } \\
\text { development of } \\
\text { industry and } \\
\text { agriculture, filling the } \\
\text { budget. } \\
\text { The limitations of } \\
\text { pressing and, } \\
\text { ultimately, the } \\
\text { elimination of } \\
\text { capitalists including ele } \\
\text { ments. }\end{array}$ \\
\hline $\begin{array}{l}\text { 1929-1936- } \\
\text { monopolizatio } \\
\mathrm{n} \text { of the } \\
\text { economy }\end{array}$ & $\begin{array}{l}\text { Resolution of the } \\
\text { CEC and RNA of } \\
\text { the USSR of March } \\
29,1931 \text { Regulation } \\
\text { "On a single } \\
\text { agricultural tax for } \\
1931 " \text { ", Consensus of } \\
\text { the } \\
\text { USSR of December } \\
5,1936\end{array}$ & $\begin{array}{l}\text { Political and liquidation } \\
\text { functions of taxation, } \\
\text { application of non- } \\
\text { systematic confiscation } \\
\text { methods of tax } \\
\text { collection; absence of } \\
\text { tax authorities. }\end{array}$ & $\begin{array}{l}\text { Liquidation kulaks, } \\
\text { spread state } \\
\text { monopoly; provision of } \\
\text { collectivization and } \\
\text { industrialization; }\end{array}$ \\
\hline
\end{tabular}

67 Крушельницька Т. А. Управління податковою системою України в умовах міжнародної економічної інтеграції : монографія. Донецьк : Юго-Восток, 2012. 412 с.

68 Крушельницька Т.А. Формування фінансової основи територіальних громад України: теоретичне визначення і аналіз актуального стану: монографія. Piga, Latvia: LAMBERT Academic Rublishing RU. 2019. $71 \mathrm{c}$. 
Continuation of the table 2

\begin{tabular}{|c|c|c|c|}
\hline 1 & 2 & 3 & 4 \\
\hline $\begin{array}{l}1936-1987- \\
\text { administrative } \\
\text { and command }\end{array}$ & $\begin{array}{l}\text { Resolution of the } \\
\text { CEC and RNA of } \\
\text { June 20,1936 "On } \\
\text { the replacement } \\
\text { of agricultural cash } \\
\text { tax from the } \\
\text { collective farms } \\
\text { income tax" Law of } \\
\text { the USSR of May } 7 \text {, } \\
1960 \text { "On the } \\
\text { abolition of the tax } \\
\text { on wages of workers } \\
\text { and employees" }\end{array}$ & $\begin{array}{l}\text { Tax abatement ; introdu } \\
\text { ction of a system of } \\
\text { privileges and } \\
\text { preferences for } \\
\text { collective } \\
\text { farms; temporary } \\
\text { increase in tax pressure } \\
\text { during the Great } \\
\text { Patriotic } \\
\text { War; strengthening the } \\
\text { absolute state } \\
\text { monopoly; full disposal } \\
\text { of state resources, } \\
\text { replacement of taxes } \\
\text { with non-tax sources of } \\
\text { filling the budget; }\end{array}$ & $\begin{array}{l}\text { Organization and } \\
\text { strengthening of } \\
\text { collective } \\
\text { farms, increase } \\
\text { of marketability of } \\
\text { production; provision } \\
\text { of military needs; the } \\
\text { use of targets and } \\
\text { benchmarks; preservati } \\
\text { on of a directive model } \\
\text { of } \\
\text { the economic mechanis } \\
\text { m, the union of two } \\
\text { opposite processes: } \\
\text { centralization in the } \\
\text { economy and } \\
\text { markets and economic } \\
\text { and regulator and. }\end{array}$ \\
\hline $\begin{array}{l}1987-1990- \\
\text { pre-market } \\
\text { transformation }\end{array}$ & $\begin{array}{l}\text { Law of the USSR of } \\
\text { June 30, } 1987 \text { "On } \\
\text { State Enterprise } \\
\text { (Association)" }\end{array}$ & $\begin{array}{l}\text { Beginning of the reform } \\
\text { of the system of } \\
\text { compulsory payments } \\
\text { of state-owned } \\
\text { enterprises in the } \\
\text { budget, formation of a } \\
\text { legal framework for } \\
\text { introducing a system of } \\
\text { taxes for individual } \\
\text { entrepreneurs, } \\
\text { cooperatives and } \\
\text { enterprises with the } \\
\text { participation of foreign } \\
\text { organizations. }\end{array}$ & $\begin{array}{l}\text { Preparation of } \\
\text { transition from } \\
\text { administrative } \\
\text { to economic methods } \\
\text { of management; stimul } \\
\text { ating the development } \\
\text { of individual } \\
\text { entrepreneurship } \\
\text { and establishing marke } \\
\text { t relations. }\end{array}$ \\
\hline $\begin{array}{l}\text { 1990-1996- } \\
\text { initial } \\
\text { institutional }\end{array}$ & $\begin{array}{l}\text { Law of Ukraine "On } \\
\text { Tax Service } \\
\text { of Ukraine" dated } \\
04.12 .1990 . \\
\text { Law of Ukraine "On } \\
\text { Value Added Tax" } \\
\text { of } 20.12 .91\end{array}$ & $\begin{array}{l}\text { The collapse of the } \\
\text { USSR, Ukraine's } \\
\text { declaration of } \\
\text { independence, and the } \\
\text { adoption of a } \\
\text { combination of market } \\
\text { and administrative } \\
\text { levers of regulation and } \\
\text { governance. }\end{array}$ & $\begin{array}{l}\text { Creation of the tax } \\
\text { system of } \\
\text { Ukraine; partial } \\
\text { alignment of } \\
\text { regulations to the } \\
\text { requirements of } \\
\text { world standards. }\end{array}$ \\
\hline $\begin{array}{l}1997- \\
\text { to } 2013- \\
\text { Reform- } \\
\text { adaptive }\end{array}$ & $\begin{array}{l}\text { Laws of Ukraine } \\
\text { "On value added } \\
\text { tax" of 03.04.1997, } \\
\text { "On taxation of } \\
\text { profits of } \\
\text { enterprises" of } \\
\text { 22.05.1997, Tax } \\
\text { Code of Ukraine of } \\
03.12 .2010\end{array}$ & $\begin{array}{l}\text { Introduction of tax } \\
\text { account; applying new } \\
\text { approaches to } \\
\text { determining the object } \\
\text { of taxation; introduction } \\
\text { of the concept of gross } \\
\text { expenditures and gross } \\
\text { revenues, formation of } \\
\text { the mechanism } \\
\text { of budgetary } \\
\text { compensation of VAT. }\end{array}$ & $\begin{array}{l}\text { Gradual adaptation of } \\
\text { the tax system of } \\
\text { Ukraine to world } \\
\text { standards, revision of } \\
\text { the principles of state } \\
\text { management of tax } \\
\text { system development }\end{array}$ \\
\hline
\end{tabular}


Continuation of the table 2

\begin{tabular}{|c|c|c|c|}
\hline 1 & 2 & 3 & 4 \\
\hline $\begin{array}{l}2014 \text { - to date } \\
- \\
\text { Reform in the } \\
\text { conditions of } \\
\text { decentralizatio } \\
\mathrm{n} \text { of power }\end{array}$ & $\begin{array}{l}\text { Law of Ukraine "On } \\
\text { Voluntary } \\
\text { Association of } \\
\text { Territorial } \\
\text { Communities" of } \\
\text { 05/02/2015, No. } \\
\text { 157-VIII, } \\
\text { Budget Code of } \\
\text { Ukraine: Law of } \\
\text { Ukraine dated July } \\
\text { 08 2010 - No. 2456- } \\
\text { VI, VRU ed. from } \\
\text { March 13. } 2015\end{array}$ & $\begin{array}{l}\text { Changing the number of } \\
\text { taxes, simplifying the } \\
\text { tax } \\
\text { legislation, introducing } \\
\text { IT- technologies of tax } \\
\text { administration, introduc } \\
\text { ing the principles of } \\
\text { budgetary } \\
\text { decentralization }\end{array}$ & $\begin{array}{l}\text { Realization of the } \\
\text { process of } \\
\text { decentralization, forma } \\
\text { tion of financial basis } \\
\text { of self-sufficiency of } \\
\text { territorial communities }\end{array}$ \\
\hline
\end{tabular}

Currently, the reform of the tax system of Ukraine is taking into account the needs of decentralization. Unfortunately, not all problems solved yet. The principles of work of fiscal institutes need to be radically changed; there is a need for transition of the process of tax administration on IT-technologies, tax law is confusing and not stable and so on. Overall, the tax system works and allows the public administration to realize the main priorities.

\section{CONCLUSIONS}

Thus, analysis and historical sources of tax system formation in Ukraine in XX - beginning of XXI century and the peculiarities of the formation of the national fiscal policy made it possible to highlight the difficult, contradictory, devoid of consistency of the path of the domestic tax system from birth to the ruins of tsarist Russia, the almost complete atrophy during the state monopoly in the USSR, and the revival with Ukraine's independence.

A retrospective analysis of the formation of the tax system of Ukraine in the XX - early XXI century revealed the dynamics of its institutions and major flaws and contradictions and its theories and (gravitational tax system to perform functions it was not typical, sharp second imbalance between the state and taxpayers, the state of permanent reform, the lack of a stable regulatory support, etc.), which will slow and today the development of the national tax system. On the example of the tax policy of the USSR in the period of the NEP and during the 30-ies of the twentieth century somewhat hypertrophied, but ideally illustrates the 
ideological positioning of the tax system in public administration to achieve the goal.

Most important result of the analysis of historical retrospective, we believe visual detection of conflict between the historical heritage in the public management of the tax system, built on the principles of administrative - command first administration and tax requirements for her systems and in the integration of Ukraine into the world economic environment and decentralization of power.

\section{SUMMARY}

The article deals with the peculiarities of implementation historical background of tax system formation in Ukraine in the twentieth - early twentieth centuries and features of national fiscal policy. These are the following periods: 1917-1921 - period forced-revolutionary, 19211929 - period forcible confiscation, 1929-1936 - period monopolization of the economy, 1936-1987 - period administrative and command, 19871990 - period pre-market transformation, 1990-1996 - period initial institutional, 1997- to 2013 - period reform- adaptive, 2014 - to date period reform in the conditions of decentralization of power. The author has distinguished stages of development of the tax system on the basis of generalization of features of each stage. This helped to characterize the priorities of fiscal policy at each stage. The article identifies conflict between the historical heritage in the public management of the tax system, built on the principles of administrative - command first administration and tax requirements for her systems and in the integration of Ukraine into the world economic environment and decentralization of power.

\section{REFERENCES}

1. Стігліц Джозеф Е. Економіка державного сектора. Пер. $з$ англ. А. Олійник, Р. Скільський. Київ. Основи, 1998. 854 с.

2. Решения партии и правительства по хозяйственным вопросам. Сборник документов. 1917-1928 гг. : в 6-и т. Москва. Издательство политической литературы, 1957. Т.1. С. 212-214. 
3. Гай-Нижник П. Податкова політика Центральної Ради, урядів УНР, Української Держави, УСРР (1917-1930рр.). Київ. Цифрадрук, 2006. 303 с.

4. Ленин В. И. Сочинения [изд. 4.]. Москва. Гос. издат. пол. литературы, тип. «Печатный двор». 1950. Т. 29. С. 118.

5. Про розкладку між губерніями зернових хлібів і фуражу, що підлягають відчуженню в розпорядження держави. Декрет РНК від 11 січня 1919 p. URL: http://www.pravoznavec.com.ua/books/letter/8/ kernel.php/624.

6. Поляков Ю.А. Переход к НЕПу и советское крестьянство. М. 1967. - C. 24-37. URL: yandex.ua/yandrearch?tex.

7. Павлюченков С.А. Орден меченосцев. Партия и власть после революции. 1917-1929. Монография. Москва. Собрание, 2008. 464 с.

8. КПСС в резолюциях и решениях съездов, конференций и пленумов ЦК. М. : Госполитиздат, 1983. Т. 2. С. 370-371.

9. Сдиний сільськогосподарський податок на 1923-24 pp. Декрет та постанова. - Х. : Видав. відділ Наркомпроду,1923. 16 с.

10. Дроздюков А. В. Итоги НЭП сквозь современную историографию. Инновационное образование и экономика. 2007. № 12 (1). С. 82-87.

11. Дэвис Р. Развитие советского общества в 20-е годы и проблема альтернативы. Россия в XX веке: историки мира спорят. М., 1994. - 314 c.

12. Рогалина Н. Л. Новая экономическая політика и крестьянство Нэп: приобретения и потери. Сборник статей. Рос. АН. ин-т рос. истории; отв. Ред. В. П. Дмитренко. М. : Наука, 1994. С. 142-143.

13. Davis R. From Tsarism to tse New Economic Policy. London. 1990. C. 62.

14. О льготах по обложению промысловым налогом для некоторых категорий предприятий : Постановление Наркомфина CCCP от 25.09.1923 URL: http://www.bestpravo.ru/sssr/ehgosudarstvo/j7b.htm.

15. О едином сельскохозяйственном налоге на 1928-29 год : Положение : Постановление ЦИК и СНК СССР от 21 апреля 1928 г. Собр. законодательства СССР. 1928. №24. С. 212. 
16. Об изменении ст. ст. 7 и 9 Положения о государственном подоходно-поимущественном налоге : Постановление ЦИК СССР, CHK CCCP от 27.07.1923 p. URL: http://www.bestpravo.ru/sssr/ehgosudarstvo/y2o.htm.

17. О введении в действие Положения о государственном подоходном налоге : Постановление ЦИК СССР, СНК СССР от 24.09.1926 URL: http://www.bestpravo.ru/sssr/eh-dokumenty/n0r.htm.

18. Поляков Ю.А. Переход к НЕПу и советское крестьянство. М. 1967. - C. 24-37. URL: yandex.ua/yandrearch?tex.

20. Литвин В. М. Криза непу. Історія України : підручник. 2011. URL: http://www.Lytvin-v.jrg.ua/history_of_ukraine/ mdex.php?article=ch.

21. Грик Н. А. Сельское хозяйство и промышленность: взаимодействие и взаимосвязь в годы первой пятилетки. 2006. URL: lib.tusur.ru/fuletext/periodika/oglavl/2006_grik_220906pdf.

22. Головко В. "Модернізація" як метанарратив української історії. Проблеми, історії Украӥни: факти, судження, пошуки : історичн. журнал. - 2003. №9. С. 410-427.

23. Мітіліно М. І. Основи фінансової науки. Київ. Державне видавництво України, 1929. 395 с.

24. Сдиний сільськогосподарський податок 1929-30 pp. : Декрет НКФ УСРР. - Харків. Укр. філія Держфінвидаву СРСР, 1929. - 48 с.

25. Про одноразовий податок на одноосібні господарства : Постанова Раднаркому УСРP від 21 листопада 1932 p. URL: http://textbooks.net.ua/content/view/1073/17/.

26. Смирнов В. С. Экономические причины кризиса социализма в СССР. Отечественная история. Москва. РАН. Ин-т рос. истории. 2002. №6. С. 97.

27. Бодров В. Г., Крушельницька Т. П., Манойленко О. В., Мартиненко В. Ф. Державне регулювання спеціальних монополій в Україні : наукова монографія. Харків. Вид-во “Константа", 2005. $320 \mathrm{c}$.

28. Конституция (основной закон) СССР от 5 декабря 1936 года (с последующими изменениями и дополнениями) URL: http://www.hist.msu.ru/ER/Etext/cnst1936.htm. 
29. О государственной налоговой службе : Постановление Совмина CCCP от 24.01.1990 N 76. URL: http://www.bestpravo.ru/ sssr/gn-akty/q0p.htm.

30. Пансков В. Г. Российские налоги. Нужна научная основа. Москва. Российский экономический журнал. 1993. № 3. С. 12.

31. КПСС в резолюциях и решениях съездов, конференций и пленумов ЦК. Москва. Госполитиздат. 1983. Т. 2. С. 370-371.

32. Про податок на холостяків, одиноких і бездітних громадян СРСР : Указ Президії Верховної Ради СРСР від 21 листопада 1941 року. Відомості Верховної Ради СРСР. 1941. № 42.

33. Цыпкин С. Правовое регулирование налоговых отношений в СССР. Москва. Госюриздат, 1955. 222 с.

34. Соколовська А. М. Методологічні аспекти оподаткування. Наукові прац̧і НДФІ. 2001. Вип. 2 (14). С. 33-39.

35. Брызгалин А. В. Налоги и налоговое право. Учебное пособие под ред. А. Брызгалина. Москва. 1997. 600 с. URL: http://www.cnfp.ru/tax/theory/history/.

36. Подписка о невыплате. Власть. 2007. № 10. URL: http://www.kommersant.ru/vlast/?IssueID=55315.

37. Жирнов Е. Отказаться от взимания налогов. Комерсант. Власть. 2010. № 17-18. URL: www.kommersant.ru/ doc.aspx? DocsID=1361006).

38. Об отмене налогов с заработной платы рабочих и служащих. Закон СССР от 7 мая 1960 года. Ведомости Верховного Совета СССР. 1960. № 18. С. 135.

39. Программа КПСС. Принята XXII съездом КПСС. Москва, 1974. C.28.

40. Леоненко П. М., Юхименко П. І. Економічна історія. Навчальний посібник. Київ. Знання - Прес. 2004. 499 с.

41. О государственном предприятии (объединении). Закон СССР от 30.06.1987. URL: http://pravo.levonevsky.org/baza/soviet/ sssr1996.htm.

42. Про державну податкову службу в Україні. Закон України від 04.12.1990 № 509-XII. Офіційний веб-сайт Верховної Ради Украӥни. URL: http://zakon3.rada.gov.ua/laws/show/509-12. 
43. Про систему оподаткування. Закон України від 25.06.1991 № 1251-XII. Офіиійний веб-сайт Верховної Ради Украӥни. URL: https://zakon.rada.gov.ua/laws/show/1251-12.

44. Про прибутковий податок з громадян : Декрет КМУ від 26.12.1992 № 13-92. Офіиійний веб-сайт Верховної Ради Украӥни. URL: http://zakon.rada.gov.ua/cgi-bin/laws/main.cgi?nreg=13-92.

45. Соколовська А. М. Податкова система України: теорія та практика становлення. Монографія. Київ. НДФІ, 2001. 372 с.

46. Про оподаткування прибутку підприємств. Закон України від 22.05.1997 р. № 283/97-ВР. Офіиійний веб-сайт Верховної Ради України. URL: http://zakon.rada.gov.ua/cgi-bin/laws/main.cgi? nreg=283\%2F97-\%E2\%F0.

47. Про податок $з$ доходів фізичних осіб. Закон України від 22.05.2003. № 889-15. Офіиійний веб-сайт Верховної Ради України. URL http://zakon2.rada.gov.ua/laws/show/889-15.

48. Крушельницька Т. А. Управління податковою системою України в умовах міжнародної економічної інтеграції : монографія. Донецьк : Юго-Восток, 2012. 412 с.

49. Крушельницька Т.А. Формування фінансової основи територіальних громад України: теоретичне визначення і аналіз актуального стану: монографія. Piga, Latvia: LAMBERT Academic Rublishing RU. 2019. 71 c.

\section{Information about the author: Krushelnytska T. A.,}

Doctor of Public Administration, Associate Professor, Professor at the Department Economy and Regional Economic Policy, Dnipropetrovsk Regional Institute of Public Administration, National Academy of Public Administration of the President Ukraine 29, Gogolia str., Dnipro, 49044, Ukraine 